\title{
Noticing Student Mathematical Thinking: Self-Contemplation of a Pre-Service Teacher
}

\author{
Serife Sevinc ${ }^{1 *}$ (1), Enrique Galindo ${ }^{2}$ \\ ${ }^{1}$ Mathematics and Science Education, Middle East Technical University, Ankara, TURKEY \\ ${ }^{2}$ Mathematics Education, Indiana University Bloomington, Indiana, USA \\ * Corresponding author: sserife@metu.edu.tr
}

Received: 23 Oct. 2021 Accepted: 11 Dec. 2021

Citation: Sevinc, S., \& Galindo, E. (2022). Noticing Student Mathematical Thinking: Self-Contemplation of a Pre-Service Teacher. European Journal of Science and Mathematics Education, 10(2), 154-169. https://doi.org/10.30935/scimath/11489

\begin{abstract}
:
This study focused on a pre-service teacher's self-contemplations about the two opportunities provided in a field experience course, Formative Assessment Interviews (FAIs) and Model Building (MB), which were designed to support pre-service teachers developing the skills of noticing students' mathematical thinking. In the field experience, pre-service teachers conducted FAIs with a pair of children and participated in MB sessions to hypothesize students' mathematical thinking. The findings suggest that although the pre-service teacher, Gloria, experienced some challenges, FAIs and MBs created a supportive medium for the pre-service teacher's development of noticing student thinking and appreciating the value of this practice, which is important to gain in teacher education.

Keywords: pre-service teacher education, noticing student thinking, field experience, formative assessment interview, mathematics education
\end{abstract}

\section{INTRODUCTION}

For teachers, it is important to notice and understand students' thinking to be able to teach effectively. Expert teachers should be able to make sense of students' work, understand students' thinking, and make appropriate instructional decisions (Lesh \& Lehrer, 2003; Mayer \& Marland, 1997). Lesh and Lehrer (2003, p. 111) expressed this importance as: "it [expertise in teaching] involves not only doing things right, but also doing the right things at the right time and with the right people." To decide on all these 'rights', teachers need to notice students' ways of thinking, including any (pre)conceptions and misconceptions they may have. To do so, they need to work with students either individually or as a group to identify their thinking, and then utilize this exploration to make appropriate decisions in designing instructional activities and selecting materials for their students (Doerr \& Lesh, 2003; Koellner-Clark \& Lesh, 2003).

Considering students' thinking while selecting instructional activities will help not only the teachers to improve their teaching practices but also the students to understand mathematics better (Carpenter et al., 1993; Lesh, 2006; McCaughtry, 2005). The Cognitively Guided Instruction (CGI) project, for instance, showed how students' achievement increased when teachers considered their solution strategies and different ways of thinking (e.g., Carpenter et al., 2000; Fennema et al., 1992). Considering this function of noticing students' thinking, teacher education programs should provide pre-service teachers with opportunities to learn to notice students' thinking and learn to use their understanding of student thinking to inform their teaching (Jacobs et al., 2010; Lingefjärd, 2002; van Es \& Sherin, 2002). 
Schorr and Lesh (2003, p. 144) pointed out the gap between the minds of a teacher and students, which is more critical for pre-service teachers because they have less experience with students than a classroom teacher does, supported by the following claim:

The teacher who has insights into students' thinking can appreciate the sense in
students' interpretations and representations of mathematical ideas, and can deal
with them constructively. By contrast, the teacher who lacks understanding of
student's thinking is left in a kind of pedagogical delusional state.

The significance of this study derives from our attempt to understand how much a field experience course can do to narrow this gap, by providing pre-service teachers opportunities to learn to notice students' thinking. Thus, we aimed to learn the story of a pre-service when she engaged in Formative Assessment Interviews (FAIs) with first grade students and Model Building (MB) of students' reasoning that were viewed as opportunities for the development of noticing of student thinking, a high-leverage teacher practice, during a field experience course.

\section{LITERATURE REVIEW}

Teacher knowledge and practices have been central to teacher development (Grossman, 1990; Grossman et al., 2009). Since understanding students' mathematical thinking requires both theory-driven knowledge and practices such as noticing and questioning (Norton et al., 2011; Schwartz, 2015), both teacher knowledge and teacher noticing literature guided this study. In this section, we also present the literature about the role of teacher education opportunities, particularly the field experience where interaction with students is possible, on pre-service teachers' understanding of student thinking.

\section{Teacher Knowledge}

According to Shulman (1986), teacher knowledge includes knowledge of what to teach (i.e., subject matter content knowledge) and how to teach (i.e., pedagogical content knowledge (PCK)). Knowledge of students' difficulties, preconceptions, misconceptions and reasoning about mathematics is a key component of the PCK (Shulman, 1986, 1987). Ball et al. (2008, p. 401) also produced a set of knowledge categories, one of which is knowledge of content and students, described as "a type of pedagogical content knowledge that combines knowing about students and knowing about mathematics." This type of knowledge highlights the importance of understanding students' mathematics to be an effective teacher.

An and $\mathrm{Wu}$ (2011) unfolded knowledge of students' thinking as (i) identifying to what extent students understood mathematics concepts, (ii) recognizing the pattern of students' misconceptions, and (iii) developing an intervention to better understand students' thinking and to remediate their misconceptions. As these components suggest, knowledge of students' thinking requires noticing students' mathematics which is often not identical to teachers' mathematics and therefore is established upon teachers' mathematical content knowledge. Research, however, has pointed out that most teachers do not have solid mathematical knowledge and sufficient teaching practices needed to understand students' mathematics (da Ponte \& Chapman, 2006). Some research also showed a close relationship between teachers' knowledge of mathematics and students' knowledge of mathematics. For example, elementary school students' lack of knowledge in geometry was found correlated with elementary teachers' (lack of) knowledge in geometry (Alatorre \& Sáiz, 2009; Hershkowitz \& Vinner, 1984). In addition to the knowledge of mathematics and the PCK, there are also practices that teachers need to engage in for understanding students' thinking. In the following section, we focus on teacher noticing and teacher questioning practices. 


\section{Noticing as a Professional Practice of Teachers}

Grossman et al. (2009) asserted a set of pedagogical practices around which the teacher education needs to be re-conceptualized. This set of clinical practices involved "practices that allow novices to learn more about students and teaching" (Grossman et al., 2009, p. 277) which encompassed selecting effective questions that would elaborate students' ideas, revoicing students' ideas properly to better understand of students' ways of thinking, and identifying misconceptions and common errors in students' thinking. These practices were incorporated in an overarching practice called professional noticing on which van Es and Sherin (2002) developed a framework called "Learning to Notice." In this framework, noticing involves three teacher actions (van Es \& Sherin, 2002, p. 573-574):

(1) identifying what is important in a teaching situation,

(2) making connections between specific events and broader principle of teaching and learning, and

(3) using what one knows about the context to reason about a situation.

Although this framework may be seen as attending to notice only in a classroom situation, teachers can resort to noticing practice in any teaching situation involving interaction with students (Barnhart \& van Es, 2015; van Es \& Sherin, 2002). Therefore, Jacobs et al. (2010, p. 172) extended this framework into "professional noticing of children's mathematical thinking" and conceptualized the aforementioned three aspects of noticing as: "attending to children's strategies, interpreting children's understandings, and deciding how to respond on the basis of children's understandings".

For the purpose of this study, we considered the Jacobs et al.'s (2010) work because the two components of the field experience course that we focused, FAIs and MBs, were designed to provide pre-service teachers with the opportunities of attending, interpreting and responding to students' mathematical thinking. For these three aspects of noticing, teacher questioning also appeared to be a core skill because the types of questions and probes that teachers posed helped them to elicit students' thinking. Schwartz (2015) considered teacher questioning as a high-leverage teacher practice because (i) questioning is a core and frequent teacher action in "the work of teaching" for any content and any teaching method, (ii) effective use of questioning has a potential to improve student learning, and (iii) teacher questioning is a competence that can be developed in teacher education and/or professional development programs.

Schwartz (2015) further argued that teacher questioning does not stand alone as a teacher skill, rather it is a practice which occurs within the interaction of content, teacher, and student. More specifically in mathematics education, teachers (a) decide the most effective questions aligning with the mathematical goal and most appropriate questions for particular students, (b) attend to student thinking related to the mathematical goal, and (c) determine the probes and follow-up questions in response to students' thinking. We agree with Schwartz (2015) in that these three actions of teacher questioning are associated with the three components of the instructional triangle (i.e., content, student, and teacher). We further see the correspondence of these three actions of teacher questioning with Jacobs et al.'s (2010, p. 172) three key aspects of "professional noticing of children's' mathematical thinking" mentioned above. Therefore, in this study, we considered professional noticing as an overarching high-leverage practice for the teaching profession and questioning as a central and essential practice for professional noticing. Not only us but also Stockero et al. (2017) viewed the teacher noticing as a high-leverage practice because it is not only a complex practice but also requires time and continuous exposure to develop.

As mentioned earlier, both questioning and noticing are not developed isolated from teacher knowledge. In fact, teachers' content and pedagogical content knowledge can increase as they attend to and notice student thinking (Jacobs et al., 2010; Norton et al., 2011; Stockero et al., 2017). In other words, when (pre-service) teachers focus on students' mathematical thinking, they also (a) attend to understand mathematics that students have reasoned through, (b) analyze their ways of thinking in terms of appropriateness and effectiveness, and (c) construct a range of responses and interactions that will improve students' ways of thinking; essential components of the PCK (Shulman, 1986, 1987). 


\section{Role of Teacher Education on Teachers' Knowledge and Noticing Practice}

Increasing attention to professional noticing practice directed researchers to investigate how to improve this practice and to consider opportunities of noticing student thinking in teacher education courses (Jacobs et al., 2010; McDuffie et al., 2014). Towards this goal, pre-service teachers were asked to watch video lessons (Barnhart \& van Es, 2015; Kleinknecht \& Gröschner, 2016; Star \& Strickland, 2008), reflect on video records of their own microteaching (Roller, 2016), participate in mediated field experience course with a focus on teacher questioning (Schwartz, 2015) and self-reflection (Kleinknecht \& Gröschner, 2016), participate in a lesson study as a part of field experience course (Amador \& Carter, 2018), conduct clinical interviews and reflect on them (Weiland et al., 2014), and model student thinking through teaching experiments (Lee, 2018). Although the theoretical and methodological approaches vary, the main focus of these studies was to investigate the ways in which pre-service teachers can develop noticing expertise.

In this sense, this research repertoire showed that pre-service teachers' engagement with practices such as questioning and interpreting student thinking on a lesson video and/or clinical interview have been found promising to improve the quality of their noticing practice. More importantly, these opportunities were integrated into teacher education courses, particularly the field-experience which provided preservice teachers with an opportunity of interacting with students in real classrooms (Kleinknecht \& Schneider, 2013; Norton et al., 2011). Particularly, Lee (2018) and Weiland et al. (2014) highlighted the importance of interviewing with children to understand their ways of thinking because interviews, on the one hand, have potential to practice teacher questioning to elicit students' thinking, and on the other hand, provide a focused context in which the classroom interruptions were removed. We agree with Lee (2018) that multiple events occurring simultaneously in the classroom setting may prevent preservice teachers' attending to student thinking, and therefore our study focused on the pre-service teacher's interviews with students where she formatively assessed student thinking and built models on their assessment. Furthermore, our study presents what the pre-service teacher thinks about how the field experience opportunities (i.e., FAIs and MBs) allowed her enactment of noticing student thinking. We, therefore, hope to contribute to the literature by articulating her awareness about the value of understanding student thinking and the challenges she experienced.

Teacher practices such as questioning, noticing and model building are important to develop in teacher education programs. Grossman et al. $(2009$, p. 278) believed that "while novices experiment with enacting such practices, they also are developing a professional identity built around their role as a teacher - the practices help elaborate their understanding of what it means to act as a teacher." Furthermore, these practices need to be planted in teacher education:
... many studies in teacher education show that student teachers do not use much of the theory taught in teacher education, Moreover, beginning teachers often complain about the fact that, once in school, they meet many problematic situations for which they were not sufficiently prepared (Korthagen \& Wubbels, 2001, p.32).

Thus, pre-service teachers' taking a real teacher role, which involves interaction with students and exploring their understanding, is an important experience that teacher education programs should provide (Barnhart \& van Es, 2015; Grossman et al., 2009; Hodson et al., 2012).

Teachers' noticing student thinking is not only an important practice but also possible to develop in teacher education and professional development (Stockero et al., 2017; van Es \& Sherin, 2008). In a study involving an intervention of video discussions, Stockero et al. (2017) observed a shift in pre-service teachers' attention from general classroom issues to specific mathematical thinking of particular students. Similarly, van Es and Sherin (2008) found a positive change in teachers' learning to notice student thinking toward the end of video club meetings. Particularly, in later club meetings, teachers paid attention more to students' mathematical thinking, discussed longer periods and in deeper ways, and maintained their focus on student thinking. Hence, in spite of the complexity of learning to notice 
(Stockero et al., 2017; van Es \& Sherin, 2008), pre-service and in-service teachers can develop a substantial practice of teacher noticing through repeated experiences in teacher education or professional development programs (McDuffie et al., 2014; Stockero et al., 2017; van Es \& Sherin, 2008).

The related literature that we summarized above showed us that the repertoire of a mathematics teacher involves a set of knowledge that constitutes a base for developing professional practices such questioning and noticing. Moreover, the relationship between the knowledge and these practices is bidirectional; that is, these practices may also contribute to the enhancement of teachers' PCK. Specifically, as pre-service or in-service teachers engage in noticing students' mathematical thinking, they could enhance their mathematical understandings through learning mathematics of the students. Being able to make sense of the students' mathematics and probing their reasoning by appropriate questions constitute crucial steps for teachers' professional noticing, and these practices could be developed through some teacher education opportunities such as regularly interviewing with students, analyzing their ways of thinking, and reflecting on those experiences. Therefore, the literature that we reviewed provided us a theoretically sound rationale that two teacher education opportunities we focused on in this study, FAIs and MBs, could have the potential for developing the skills of noticing students' mathematical thinking and provided us a theoretical lens to analyze and discuss the findings.

\section{METHODS}

With a case study orientation, we investigated a pre-service teacher's self-contemplation on noticing students' thinking during a field experience which was structured based on the Iterative Model Building Project (NSF Grant DRL-0732143). The pre-service teacher, Gloria, who is the focus of this case study, was observed in the field and interviewed at the end. The setting of this study, the field experience course at a large Midwestern University in the U.S., was designed based on teaching experiments (Steffe \& Thompson, 2000) and lesson study (Lewis, 2000). Since the focus of this study is on the role that two specific adaptations of the teaching experiment methodology, FAIs and MBs, in a field experience course, we provide a brief description below to set a methodological base.

\section{Teaching Experiment Methodology}

Teaching experiments are designed to explore students' thinking through a series of teaching episodes (Steffe \& Thompson, 2000, p. 273):

A teaching episode includes a teaching agent, one or more students, a witness of the teaching episodes, and a method of recording what transpires during the episode. These records, if available, can be used in preparing subsequent episodes as well as in conducting a retrospective conceptual analysis of the teaching experiment.

The key feature of a teaching experiment is involvement of not one but a series of teaching episodes including interaction with students, which results with a contribution to student's mathematical construction and instant analysis of what might be going on in the student's head (Steffe, 1991). Due to this nature of teaching experiments, the researcher is usually called a "teacher-researcher." To briefly describe the process, teaching experiments require researchers recording their interaction with students and engaging in the videotape analysis to produce a model of students' thinking which helps them communicate with colleagues about students' mathematics and design the following episode (Steffe \& Thompson, 2000). This communication enhances the quality feedback from peers (Tang \& Chow, 2007) and fosters self-assessment (Sadler, 2005) since teacher-researchers evaluate their models of student thinking which was built individually and compared with the feedback from peers.

The analysis of students' reasoning can be done both retrospectively with the focus on what students did know about a particular mathematical topic and prospectively with the focus on what they might know about related topics. The model produced by the teacher-researcher not only describes a particular student's view in a particular setting but also displays a general picture to give insights about other 
students' mathematical thinking (Steffe \& Thompson, 2000). Furthermore, the model building process allows the teacher-researcher not only to formulate a hypothesis about students' mathematical reasoning but also to test and revise their hypothesis about students' thinking (Steffe \& Cobb, 1983; Steffe \& Thompson, 2000) and in this sense have been a successful tool to understand students' thinking: "Learning children's mathematical knowledge is part of what it means to be a mathematics teacher and no one else can assume this responsibility for the teacher" (Steffe, 1991, p. 188). Hence, model building is considered as an important practice for teachers which is, in nature, similar to teacher noticing practice.

Therefore, the role of continuous experiences of clinical interviews and noticing students thinking was suggested as a valuable research area (Jenkins, 2010; Lee, 2018). Following this suggestion, we seek to provide some insights into the matter that the two adaptations, FAIs and MBs, can help pre-service teachers notice students' thinking.

\section{Case Study Participant and Setting}

To select the case participant, a group of six pre-service teachers was observed during a semester-long field experience. Due to her interest in communicating with students, Gloria ${ }^{1}$ was invited to participate in this study. Following Institutional Ethics Committee procedure, Gloria was given an informed consent including the interview questions approved by Institutional Review Board (IRB). Even though she showed a great interest in interviewing students, her performance in FAI and MB sessions was not very different from that of other pre-service teachers in the field experience course. Thus, we considered Gloria to represent a typical pre-service teacher in her group. Gloria, a female 20-year-old pre-service teacher, was a junior in the Elementary Education program at a large Midwestern University in the United States and was assigned to teach in a first-grade classroom as a part of the field experience course. Although Gloria was not considerably different from other pre-service teachers, we selected only one pre-service teacher to track her interviews with students, model building sessions, her teaching at the first-grade classroom, and her questions to the teacher educator and interactions with her peers. In this study, we focused only on FAIs and MBs; however, we observed her throughout the semester at all parts of the field experience and interviewed with her at the end of the semester. Among the six preservice teachers, we focused on Gloria as our case participant because she was the only one who provided the consent for being observed and recorded at all stages of the field experience throughout the semester. In this sense, the case participant selection was based on the participant's own volition.

\section{Field experience course}

The weekly field experience sessions included four main parts: (1) Workshops, (2) FAIs, (3) MBs, and (4) Teaching and Lesson Study. Figure 1 illustrates the design of the field experience course. The workshops, offered by a teacher educator, aimed to prepare pre-service teachers for teaching, FAIs, MBs, and Lesson Study. In FAIs, groups of three pre-service teachers interviewed two students to learn about their mathematical understanding and wrote a reflection. The three pre-service teachers in each group alternated weekly sharing responsibilities of being interviewer (i.e., responsible to ask questions and probe students' thinking), video recorder, or note taker and completed six-week-long mathematicsfocused FAIs with the same pair of students. Among six FAIs, Gloria took the interviewer role in the third and sixth weeks; thus mid- and end-of-the mathematics portion of the field experience.

MB sessions required pre-service teachers to explore one student's mathematical reasoning deeply and build models of student thinking. To do so, the pre-service teacher, who made the interview, transcribed the sections that she identified as important and then analyzed to model student's thinking. This

\footnotetext{
1 The name of the case participant and the names of the first-grade students who she interacted with are pseudonyms.
} 


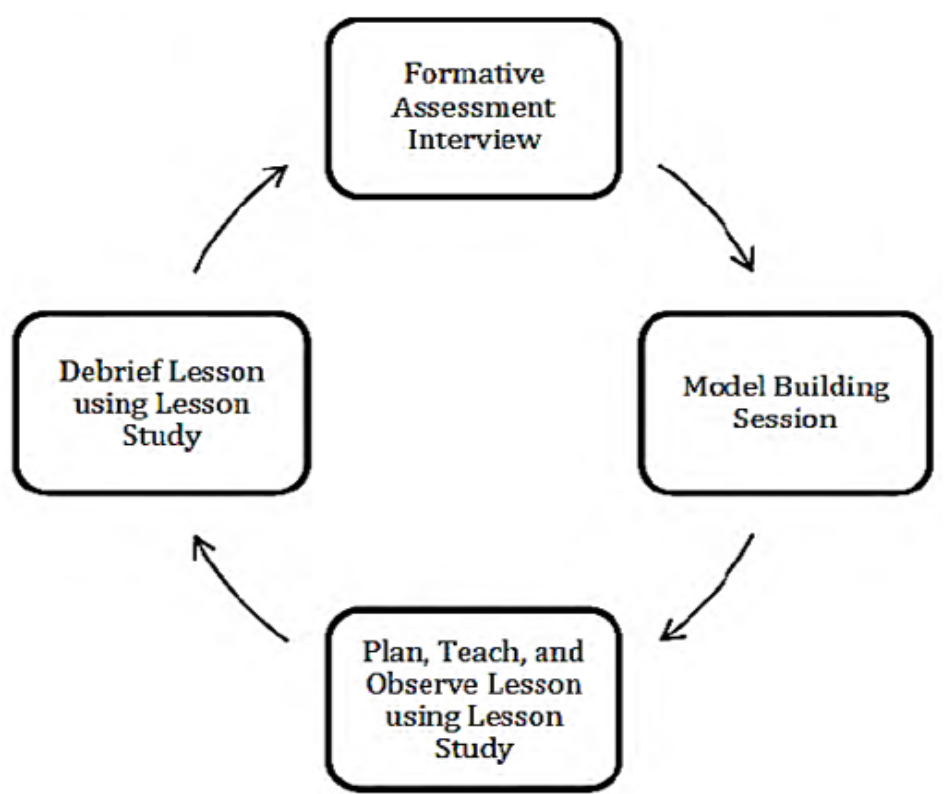

Figure 1. Design of the field experience course

individual MB session was followed by group MB session where other pre-service teachers watched the selected sections, read the transcription, hypothesized models of student thinking and commented on their peer's model. Gloria participated in two kinds of group MB sessions: (1) four sessions in which Gloria was not an interviewer but contributed group discussion, and (2) two sessions in which Gloria was the interviewer and the leader of the group discussion.

The last part of the field experience session was teaching and conducting an adaption of lesson study (Lewis, 2000). For this part, a pair of pre-service teachers prepared math lessons based on their models of student thinking developed in MB sessions. While this pair of pre-service teachers were teaching, other pre-service teachers observed their peers and students. Afterward, pre-service teachers and the classroom teacher came together and discussed the weakest and strongest points of the lesson, possible revisions to improve it, and how the current experience could inform the following lessons, yet lesson study part of the field experience was not included in this study.

\section{Data Analysis Process}

The data set included (a) audio record of the interview with Gloria, (b) video record ${ }^{2}$ of an FAI conducted by Gloria, (c) six FAI reflections, (d) two MB handouts prepared by Gloria, (e) video record of MB session orchestrated by Gloria and (f) video records of MB sessions that Gloria did not orchestrate but contributed. The first author participated in the field experience course throughout the semester, observed Gloria during FAIs and MBs, and kept a reflective journal. Data analysis procedure mainly involved transcription of audio and video data, coding, thematizing and member checking.

\section{Transcription methods}

For video segments in which the conversation between Gloria and students is important to analyze deeply, condensed gisted transcription was used removing unnecessary words, but having exact words (Paulus et al., 2014). For the audio record of the interview, researchers used verbatim transcription aiming to capture the exact words of the pre-service teacher along with all utterances.

\footnotetext{
${ }^{2}$ Only three of the six FAIs and MB sessions conducted by Gloria's group were video-recorded. However, thick descriptions and detailed observation notes were taken for other three FAIs and MBs.
} 


\section{Coding, thematizing and triangulation}

To analyze video data and reflection papers, we used descriptive coding to understand what is happening and in-vivo coding to understand what the pre-service teacher and students call for what is happening (Saldaña, 2009). During video data coding, we focused on what the pre-service teacher did and said during the FAIs, how she used the opportunities to notice students' thinking, whether there is evidence in the record to support her conclusions about students' thinking, and how she contemplated the opportunities of noticing student thinking. Thus, on video data, the coding unit constitutes each statement and utterance that Gloria presented, either consciously or unconsciously. The interview data were coded in two cycles. In the first cycle, in-vivo coding and initial coding were used. During initial coding, the bids of information were named without any restriction of the theory and being open to all possible directions of the study (Saldaña, 2009). In the second cycle, focused coding was used to make sense of Gloria's experiences and to categorize the codes produced in the initial coding. Thus, this second cycle also served for thematization (see Appendix for the list of codes, categories, and themes). The coding unit for the interview data was mainly Gloria's expressions (i.e., phrases and sentences).

Altogether we used three different types of data, written reflections, the audio record of the interview, and video records of FAI and MB, in order to triangulate our interpretations about Gloria's experiences and thoughts. We also conducted member checking by showing Gloria our codes and interpretations. First author's reflective journal provided a thick description of her role as a researcher during data collection and data analysis and therefore was considered as another way to ensure credibility (Creswell, 2007).

\section{The Researcher Role}

Creswell (2007) asserted that it is important to provide a thick description about the researchers' role in data collection and data analysis in order to ensure the quality of the study because, in a qualitative study, the data come from both the participants and the researcher. That is, the researcher as an interviewer or observer is a part of the data (Patton, 2002). The first author participated in the field experience course throughout the semester and observed the pre-service teacher during FAIs, MBs, lessons and lesson studies. She kept a reflective journal during data collection and analysis processes. The following excerpt was taken from her reflective journal.

Today, I caught up a first-grader's eyes on me and asked myself: Who am in this field? I was not one of the pre-service teachers who was teaching students; I was not the instructor of pre-service teachers who usually had communication with students' own teacher; I was not one of the parents. So, who was I in that classroom? I really feel myself as an outsider to this community. Coming from a different country, a different culture; I am not familiar with the school system and classroom culture in the U.S. Considering this, I can only say to myself that I am a curious eye in this field to learn more about how effective this field experience is for pre-service teachers in terms of learning to teach, learning how students think and learning how to relate understanding of students' thinking to lesson planning.

These reflective notes helped the researcher to understand her role as a researcher in the field experience. Being an insider to some extent but mostly being an outsider helped the researcher to maintain a balanced relationship with the pre-service teacher. In other words, she was neither the course instructor who would evaluate pre-service teachers nor a close friend, but more like a person who they can come to for suggestions, help at any time in the field, and share any thoughts without hesitation of being assessed. We believe that this role of the researcher helped to reduce the bias of the participant in data collection and bias of the researcher in data analysis. 


\section{FINDINGS}

Jacobs et al.'s (2010) framework on professional noticing involved (i) eliciting and attending, (ii) analyzing and interpreting, and (iii) responding and probing students' thinking. While all three actions could be observed in FAIs where pre-service teachers attended to understand student's thinking, instantly interpreted them and probed to notice details of students thinking, they experienced the second step (i.e., interpreting student thinking) at a deeper level during individual and group MB sessions. Thus, Gloria's self-contemplation about FAIs and MBs that we present below tells us her story of noticing two first-grade students' thinking.

\section{The Challenges and Benefits of FAls for Noticing Students' Thinking}

The goal of Gloria's FAI in which she had the interviewer role was to understand students' thinking about the characteristics of 2-D geometric shapes. To achieve this purpose, she mainly asked two firstgrade students to examine the differences and similarities between the two triangles that they created on the geoboard.

During FAIs, one issue that we focused on was the way of teacher questioning because it determines to what extent students' thinking could be elicited. In this regard, we attended the language Gloria used while questioning. Gloria often used mathematical terms like "edges, sides, and vertices" while asking questions, which indicated that she took students' knowledge of mathematical terminology for granted instead of ascertaining their knowledge of triangles. The following dialogue illustrates how using mathematical terms prevented her from getting rich responses from students, and how the language used can become an obstacle to notice student thinking.

Gloria: Ok. How did you know that this triangle is different from the one that you had first created?

Claire: Because it is bigger.

Gloria: Because it is bigger? Ok. Is there any other difference? Do you see any other difference between the first one that you have made and this one in terms of the edges or the sides?

Claire: [pointed her finger along the side of the triangle] The sides are bigger.

Gloria: The sides are bigger. What about the vertices or the points, how are they different?

Claire: Thee..., they are kind of smaller.

Gloria: They are kind of smaller. Jack, what about you? How are the sides on that triangle different from the sides on the one that you have first created?

Jack: [pointed to one of the pegs inside the triangle] Umm, big, big.

Gloria: They're bigger?

Jack: Yeah.

Gloria: What about the vertices or the points? What is different about that?

Jack: They are a little smaller.

Gloria: They are a little smaller? 
Jack: Yeah.

Gloria: Ok. What is similar? What is the same between the triangles that you made?

What is something that is the same?

Jack: Ummn, the sides are the same.

Gloria: The same, like they are the same length?

Jack: Yeah.

Gloria: Or [do both triangles have] the same number of sides?

Jack: They are the same sides.

From this conversation, it seems that Gloria attended the student's comparison strategy that depended on the size of triangles. Gloria also probed students' thinking by asking them whether they saw any difference in terms of edges or sides (i.e., the second question on the above excerpt). Yet, this question involved two terminologies, "edge" and "side" that she (and we) did not know whether students heard them before. Her further probe also added another term "vertices" but this time she added a descriptive word, "vertices or points." Still, we observed that using terminology-involved questions created an obstacle for attending students' strategies. For instance, when Gloria asked about the differences between the two triangles in terms of vertices, both students said that they were smaller. Since she did not probe students' thinking at that moment, she could not identify what students were actually thinking about the term vertex and about vertices' getting smaller. Thus, not being able to select and ask appropriate questions at the appropriate time resulted in insufficient interpretation about students' thinking (Schwartz, 2015).

Gloria expressed that she found mathematics FAIs easier to carry out because she felt herself more comfortable in mathematics than in science and therefore could ask the same mathematics question in different ways to get rich information about students' thinking. This perception confirms the importance of questioning in professional noticing practice (Jacobs et al., 2010; Schwartz, 2015); the more effective and appropriate questions the teacher asks, the more evidence s/he can get about student thinking. Gloria's point also confirms many researchers in that the practice of teachers' noticing feeds and is fed by teachers' confidence in the content knowledge (e.g., Jacobs et al., 2010; Norton et al., 2011; Stockero et al., 2017). In addition, not only the questions themselves but also the way and the tone of questioning matters for Gloria to attend and properly probe students' thinking: "If students feel like they were quizzed, they may force themselves to find the right answer instead of brainstorming." She also reflected on some challenges regarding students' characteristics such as the difficulty of identifying the quiet student's thinking during the FAI:

\footnotetext{
It was too hard sometimes because we had one student who was very talkative and one that did not talk and she [the quiet student] was like "whatever he [the talkative student] said." And so it was hard to take it and balance both of their ideas when we did together... I think it was definitely more challenging to figure out what she is thinking.
}

To understand the quiet student's thinking, she found manipulatives useful. As she self-contemplated, even though the student could not explain her thinking, what she did with manipulatives constituted evidence for Gloria. Hence, manipulatives served as an assistive tool for Gloria to attend students' thinking, particularly in mathematics. For instance, she used unifix cubes in some interviews that helped students to show their ways of thinking, where showing was easier for them than just explaining 
verbally. Another example was in the geometry interview, a part of the transcript of which was given above. Gloria used some cut-out shapes and asked students to categorize according to their similarities and observed that students, and particularly the quiet student, expressed his/her way of thinking about commonalities between all triangles better than his/her verbal explanation above. Thus, with the help of the concrete tools, Gloria could understand that the number of sides was the main characteristic that students paid attention to, but the size of the triangles interfered their understanding of triangles. This observation with the help of materials consolidated Gloria's understanding of students' thinking of the triangles. Lastly, Gloria perceived FAIs as exciting and useful activities of the field experience. The following excerpt presents some of her thoughts in detail:

I think it was really cool. I have never done anything like that before. ... I think that it was really helpful in hearing what they [students] were saying... After the first couple weeks, we were like, "ohh, did you hear what Jack said"... I guess other field experiences, you just kind of go in and you try to help them and you are teaching them but you are not really asking questions. Yeah, I feel like, it put us more in [the] teachers' position.

Gloria thought that the FAIs allowed her to directly communicate with students and develop a teacher identity. In this respect, FAIs were considered as unique experiences which let pre-service teachers notice students' thinking, an important step towards developing a teacher identity and towards becoming a teacher.

\section{The Challenges and Benefits of MBs for Interpreting Students' Thinking}

As mentioned earlier, Gloria experienced two kinds of $\mathrm{MB}$ sessions in the field experience course to interpret students' thinking. In the first kind, Gloria was not the interviewer and so was not active in attending, responding, and probing students' thinking but contributed group MB discussion session by interpreting students' thinking. In the second kind, Gloria was the interviewer and so was active in all three aspects of noticing practice; namely attending, interpreting, and probing students' thinking.

According to Gloria, a model was "what the student is thinking," which was often similar to other students' thinking: “...it is a model for one person but it is probably a model for several students." She thus implied that even though she had the chance of investigating only two students' thinking, this gave her an insight into models of other students at the same grade level. In this respect, Gloria was aware that $\mathrm{MB}$ sessions were serving for learning to notice and interpret students' thinking. For the first kind of MB sessions, we observed that Gloria's level of confidence in identifying students' thinking improved toward the end of the semester. For instance, on the first MB video, Gloria's noticing student thinking was more superficial, descriptive and confirmative of her peer's thinking about the students' mathematical thinking: "Yes, as you said, she relied on manipulatives." On the other hand, during the $5^{\text {th }}$ week's MB group discussion session, she proposed many "what if" situations such as "how could the student respond if we stated the question differently," attending to understand students' thinking in related but various situations. In such instances, Gloria attended not only to notice a range of possible thinking the student might have but also to reach a model of student thinking which would be as general as possible; that is, the ways of thinking that would be valid for similar instructional situations. Both specificity and generality are two characteristics of noticing in that noticing involves both identifying particular ways of thinking for a particular instructional situation and seeking for the pattern of responses to predict ways of thinking in similar situations (Lee, 2018). In this sense, we viewed Gloria's attending to student thinking throughout six MB sessions as potential improvement of her professional noticing practice. 
In the second kind of MB experience, Gloria focused on the quiet student, Claire. She wrote in the MB handout that Claire's thinking was based on "what the triangle looks like;" and interpreted as visualdependent by relating it to the first level of van Hiele's geometric thought (Gutiérrez \& Jaime, 1998). Moreover, she thought that Claire did not understand the common characteristics of triangles (i.e., 3 sides and 3 vertices) because she did not put skinny triangles into the category of triangles. However, the video record of the FAI showed that Claire, in fact, counted the number of pegs along the sides and stated that the new triangle is bigger (see the excerpt in the previous section). This indicated that Claire could have used the length of the sides of a triangle to compare with another triangle but might not have used this knowledge to classify triangles. If Gloria had asked Claire why she counted the number of pegs and what she figured out after counting them, this would have helped to identify her thinking deeply. Hence, we observed that Gloria could not probe student's thinking effectively, and this resulted in insufficient and even misled interpretation about student thinking.

For the second kind of MB sessions, pre-service teachers transcribed segments of the FAI. Gloria found this transcription process useful since it helped her notice the pauses which seemed obvious in conversation but could give a clue about students' thinking. Therefore, transcription of the interview appeared as another assistive opportunity for noticing students' thinking although the chance of responding and probing was already lost in this case because transcription happened after the interview was done. Gloria thought that learning her peers' perspective during MB group discussion was also helpful because they could catch nuances in student's thinking that she had missed. Hence, MB facilitated Gloria's awareness of the details in students' thinking with the help of group discussion with peers and individual investigation involving transcription of segments of FAI.

\section{CONCLUSIONS AND DISCUSSION}

Gloria's reflection on her development throughout the field experience indicated that she felt she had improved her skills and confidence in noticing students' thinking. We think that nothing but her own words can express this change:

I think it has been helpful in figuring out what individual students are thinking...I don't remember so much like what we had done for science and math [in the school] when I was a kid, and how that worked. So, I think [the] field experience was helpful to learn a lot of new ways to think about what students are thinking... Yeah, that was definitely something that changed. I think I am probably more confident in that.

As she indicated that recalling how she, herself, learned mathematics in schools was not sufficient to notice students' mathematical thinking. Thus, Gloria's self-contemplation indicated that interviewing with students and deeply analysing these interviews helped her notice students' thinking. She, therefore, viewed FAI and MB sessions as useful components of the field experience. More importantly, those experiences helped her to put herself in a teacher position in which she communicated with students mathematically, created a motivation for pre-service teachers to improve their knowledge and skills (Hodson et al., 2012) during pre-service teacher education (Grossman et al., 2009; SánchezMatamoros et al., 2015). In this sense, these experiences helped to narrow the gap between pre-service teacher's and students' mind in terms mathematical thinking (Schorr \& Lesh, 2003), even before they become a teacher in their own classroom.

The challenges that Gloria experienced in noticing students' thinking indicated the importance of teachers' content knowledge in order to understand students' thinking. As Gloria herself mentioned, she was hesitant to produce probing questions about the topics that she felt a lack of content knowledge (i.e., science). Teachers' superficial level of noticing was also found, in some studies, correlated with the 
lack of their content knowledge (Hershkowitz \& Vinner, 1984; Star \& Strickland, 2008). Although Gloria expressed her confidence in mathematics, there were still instances where she could not notice the student's thinking substantially during FAIs. For instance, when the student was counting the number of pegs on the geoboard to make sense of the side length of a triangle, she could not attend to student's mathematical thinking (i.e., what she identified by counting the pegs). At another instance, she could not articulate the space inside the triangle pointed by the student as area, a property of a shape to make a comparison. Although we do not have enough evidence to claim that these were due to the lack of her content and pedagogical content knowledge, there was clearly a lack of noticing students' mathematical thinking. Since counting the marks instead of distances was one of the common misconceptions of students while determining the side length and since the area of a shape indicates the two-dimensional space that the shape covers, we think that Gloria either did not possess or did not use this knowledge in these instances. Therefore, this lack of noticing may be related to the lack of her content knowledge and pedagogical content knowledge or the lack of her experience with students, parallel to the conclusions that Star and Strickland (2008) reached in their study on pre-service teachers' noticing.

Other researchers also claimed that understanding students' mathematical thinking requires teachers to have solid mathematical knowledge (Alatorre \& Sáiz, 2009; da Ponte \& Chapman, 2006; Hershkowitz \& Vinner, 1984), pedagogical content knowledge (Shulman, 1986, 1987), and knowledge of content and students (Ball et al., 2008). That is, pre-service and in-service teachers should have conceptual mathematics knowledge to make sense of students' mathematical reasoning, misconceptions, and errors because conceptual connections among mathematical ideas and procedures help teachers figure out students' mathematical reasoning and deciding the best probing questions which will delve into students' mathematics. In this sense, Sánchez et al.'s study (2015) supports our claim because the researchers found that pre-service teachers' improvements on noticing student thinking were supported by their "recognition of the mathematical elements used by the students to solve the problems" (p. 1324).

In addition, both FAIs and MBs appeared to be useful for Gloria but not easy to accomplish. In fact, noticing students' mathematical thinking, itself, is a complex practice to develop for a preservice teacher (Jacobs et al., 2010; McDuffie et al., 2014; Sánchez et al., 2015). For Gloria, one of the major challenges was not being able to probe and interpret students' thinking efficiently. The research on noticing also acknowledged pre-service teachers' such challenges (Barnhart \& van Es, 2015; Chung \& van Es, 2014). Therefore, most studies used video analysis to help pre-service and in-service teachers recall the instructional situation accurately (and repeatedly if necessary) and search for the evidence of student thinking (McDuffie et al., 2014; Star \& Strickland, 2008). Particularly group MB sessions helped Gloria improve her interpretations of students' thinking. The positive impact of peer-sharing on pre-service teacher's development was also well-known in other research (e.g., Danielowich, 2014; Hodson et al., 2012). Furthermore, the use of manipulatives and transcribing the conversation between students assisted Gloria to notice students' mathematical thinking.

Hence, we claim that pre-service teachers' interacting with students provides them with a good opportunity to become more proficient in identifying the best probing questions for particular students and thus opens the door for better understanding of students' reasoning (Doerr \& Lesh, 2003; Grossman et al., 2009; Koellner-Clark \& Lesh, 2003). As Jenkins (2010) argued, not only examining students' written solutions but also interviewing with students help teachers notice students' mathematical thinking. Furthermore, when these interactions with students become repeated experiences, pre-service teachers can notice students' thinking at a deeper level (McDuffie et al., 2014; Stockero et al., 2017; van Es \& Sherin, 2008). In our case study, we observed this effect to a higher degree because Gloria experienced a series of FAIs and MBs with the same pair of students during her field experience and had the opportunity to improve her noticing practice in order to get the best approximation of student's 
mathematical thinking. However, these conclusions are limited to the story of only one pre-service teacher, Gloria, in this case study. Laying out the stories of other pre-service teachers and making crosscomparisons of these stories may reveal other issues that play an important role in noticing student thinking. The second limitation of this study is focusing on only two components of field experience course, FAI and MB. We believe that including the third component (i.e., lesson study) to this investigation may provide a clearer and broader picture of the pre-service teacher's noticing experiences.

In conclusion, this study indicated that FAI and MB can serve as supportive experiences in teacher education programs because they helped Gloria improve her skills and confidence in noticing students' thinking (Grossman et al., 2009). Indeed, FAIs and MBs positioned pre-service teachers as teachers who are regularly communicating with students and noticing students' mathematical thinking during their interactions with students, and therefore, provided pre-service teachers a medium closer to that of a future classroom teaching setting. We believe that looking into how pre-service teachers utilized students' thinking elicited through FAIs and MBs while lesson planning and teaching (McCaughtry, 2005) and examining how much of what pre-service teachers learned in the field experience is carried into their future practice as teachers are other important questions to investigate.

\footnotetext{
Author contributions: All authors were involved in concept, design, collection of data, interpretation, writing, and critically revising the article. All authors approve final version of the article.

Funding: The research reported in this paper was supported in part by a DR-K12 grant from the National Science Foundation (NSF), under Grant DRL-0732143.

Declaration of interest: Authors declare no competing interest.

Data availability: Data generated or analysed during this study are available from the authors on request.
}

\section{REFERENCES}

Alatorre, S., \& Sáiz, M. (2009). Teachers and triangles. In V. Durand-Guerrier, S. Soury-Lavergne, \& F. Arzarello (Eds.), ProceedingS of CERME 6-working group 10 (pp. 1980-1900). INRP.

Amador, J. M., \& Carter, I. S. (2018). Audible conversational affordances and constraints of verbalizing professional noticing during prospective teacher lesson study. Journal of Mathematics Teacher Education, 21, 5-34. https://doi.org/10.1007/s10857016-9347-x

An, S., \& Wu, Z. (2012). Enhancing mathematics teachers' knowledge of students' thinking from assessing and analyzing misconceptions in homework. International Journal of Science and Mathematics Education, 10(3), 717-753. https://doi.org/ 10.1007/s10763-011-9324-x

Ball, D. L., Thames, M. H., \& Phelps, G. (2008). Content knowledge for teaching: What makes it special? Journal of Teacher Education, 59(5), 389-407. https://doi.org/10.1177/0022487108324554

Barnhart, T., \& van Es, E. (2015). Studying teacher noticing: Examining the relationship among pre-service science teachers' ability to attend, analyze and respond to student thinking. Teaching and Teacher Education, 45, 83-93. https://oi.org/ 10.1016/j.tate.2014.09.005

Carpenter, T. P., Fennema, E., \& Romberg, T. A. (Eds.). (1993). Rational numbers: An integration of research. Lawrence Erlbaum Associates.

Carpenter, T. P., Fennema, E., Franke, M. L, Levi, L., \& Empson, S. B. (2000). Cognitively guided instruction: A research-based teacher professional development program for elementary school mathematics (National Center for Improving Student Learning and Achievement in Mathematics and Science, Report No. 003). Wisconsin Centre for Education Research. The University of Wisconsin-Madison.

Chung, H. Q., \& van Es, E. A. (2014). Pre-service teachers' use of tools to systematically analyze teaching and learning, Teachers and Teaching: Theory and Practice, 20(2), 113-135. https://doi.org/10.1080/13540602.2013.848567

Creswell, J. W. (2007). Qualitative inquiry and research design: Choosing among five approaches. Thousand Oaks, CA: Sage.

Da Ponte, J. P., \& Chapman, O. (2006). Mathematics teachers' knowledge and practices. In A. Gutiérrez \& P. Boero (Eds.), Handbook of research on the psychology of mathematics education: Past, present and future (pp. 461-494). Sense Publishers. https://doi.org/10.1163/9789087901127_017

Danielowich, R. M. (2014). Shifting the reflective focus: Encouraging student teacher learning in video-framed and peer-sharing contexts, Teachers and Teaching: Theory and Practice, 20(3), 264-288. https://doi.org/10.1080/13540602.2013.848522 
Doerr, H. M., \& Lesh, R. (2003). A modeling perspective on teacher development. In R. Lesh \& H. M. Doerr (Eds.), Beyond constructivism: A models and modeling perspective (pp. 125-140). Lawrence Erlbaum Associates.

Fennema, E., Carpenter, T. P., \& Franke, M. L. (1992). Cognitively guided instruction. The Teaching and Learning of Mathematics, $1(2), 5-9$.

Grossman, P. L. (1990). The making of a teacher: Teacher knowledge and teacher education. New York: Teachers College Press.

Grossman, P., Hammerness, K., \& McDonald, M. (2009). Redefining teaching, re-imagining teacher education, Teachers and Teaching: Theory and Practice, 15(2), 273-289. https://doi.org/10.1080/13540600902875340

Gutiérrez, A., \& Jaime, A. (1998). On the assessment of the Van Hiele levels of reasoning. Focus on Learning Problems in Mathematics, 20, 27-46.

Hershkowitz, R., \& Vinner, S. (1984). Children's concepts in elementary geometry: A reflection of teacher's concepts? In B. Southwell (Ed.), Proceedings of the 8th PME International Conference (pp. 63-69). Darlinghurst, Australia: Mathematical Association of New South.

Hodson, E., Smith, K., \& Brown, T. (2012). Reasserting theory in professionally based initial teacher education, Teachers and Teaching: Theory and Practice, 18(2), 181-195. https://doi.org/10.1080/13540602.2012.632269

Jacobs, V. R., Lamb, L. L., \& Philipp, R. A. (2010). Professional noticing of children's mathematical thinking. Journal for Research in Mathematics Education, 41, 169-202. https://doi.org/10.5951/jresematheduc.41.2.0169

Jenkins, O. F. (2010). Developing teachers' knowledge of students as learners of mathematics through structured interviews. Journal of Mathematics Teacher Education, 13(2), 141-154. https://doi.org/10.1007/s10857-009-9129-9

Kleinknecht, M., \& Gröschner, A. (2016). Fostering preservice teachers' noticing with structures video feedback: Results of an online- and video-based intervention study. Teaching and Teacher Education, 59, 45-56. https://doi.org/10.1016/ j.tate.2016.05.020

Kleinknecht, M., \& Schneider, J. (2013). What do teachers' think and feel when analyzing videos of themselves and other teachers teaching? Teaching and Teacher Education, 33, 13-23. https://doi.org/10.1016/j.tate.2013.02.002

Koellner-Clark, K., \& Lesh, R. (2003). A modeling approach to describe teacher knowledge. In R. Lesh \& H. M. Doerr (Eds.), Beyond constructivism: A models and modeling perspective (pp. 159-173). Lawrence Erlbaum Associates.

Korthagen, F. A. J., \& Wubbels, T. (2001). Learning from practice. In Linking practice and theory: The pedagogy of realistic teacher education (pp. 32-50). Mahwah, NJ: Lawrence Erlbaum. https://doi.org/10.4324/9781410600523

Lee, M. Y. (2018). Further investigation into the quality of teachers' noticing expertise: A proposed framework for evaluating teachers' models of students' mathematical thinking. EURASIA Journal of Mathematics, Science and Technology Education, 14(11), 1-15. https://doi.org/10.29333/ejmste/92019

Lesh, R. (2006). New directions for research on mathematical problem solving. http://citeseerx.ist.psu.edu/viewdoc/download?doi=10.1.1.554.5643\&rep=rep1\&type=pdf

Lesh, R., \& Lehrer, R. (2003). Models and modeling perspectives on the development of students and teachers. Mathematical Thinking and Learning, 5(2, 3), 109-129. https://doi.org/10.1080/10986065.2003.9679996

Lewis, C. (2000). Lesson study: The core of Japanese professional development [Paper presentation]. Annual Meeting of the American Educational Research Association, New Orleans, LA, USA.

Lingefjärd, T. (2002). Teaching and assessing mathematical modeling. Teaching Mathematics and Its Applications, 21(2), 75-83. https://doi.org/10.1093/teamat/21.2.75

Mayer, D., \& Marland, P. (1997). Teachers' knowledge of students: A significant domain of practical knowledge? Asia-Pacific Journal of Teacher Education, 25, 17-34. https://doi.org/10.1080/1359866970250103

McCaughtry, N. (2005). Elaborating pedagogical content knowledge: What it means to know students and think about teaching, Teachers and Teaching: Theory and Practice, 11(4), 379-395. https://doi.org/10.1080/13450600500137158

McDuffie, A. R., Foote, M. Q., Bolson, C., Turner, E. E., Aguirre, J. M., Bartell, T. G., Drake, C., \& Land, T. (2014). Using video analysis to support prospective K-8 teachers' noticing of students' multiple mathematical knowledge bases. Journal of Mathematics Teacher Education, 17, 245-270. https://doi.org/10.1007/s10857-013-9257-0

Norton, A., McCloskey, A., \& Hudson, R. A. (2011). Prediction assessments: Using video-based predictions to assess prospective teachers' knowledge of students' mathematical thinking, Journal of Mathematics Teacher Education, 14, 305-325. https://doi.org/10.1007/s10857-011-9181-0

Patton, M. Q. (2002). Qualitative research and evaluation methods (3rd ed.). Sage.

Paulus, T., Lester, J., \& Dempster, P. (2014). Digital tools for qualitative research. Sage. https://doi.org/10.4135/ 9781473957671

Roller, S. (2016). What they notice in video: A study of prospective secondary mathematics teachers learning to teach. Journal of Mathematics Teacher Education, 19, 477-498. https://doi.org/10.1007/s10857-015-9307-x

Sadler, D. R. (2005). Interpretations of criteria-based assessment and grading in higher education, Assessment $\mathcal{E}$ Evaluation in Higher Education, 30(2), 175-194. https://doi.org/10.1080/0260293042000264262

Saldaña, J. (2009). The coding manual for qualitative researchers. Sage Publications. 
Sánchez-Matamoros, G., Fernández, C., \& Llinares, S. (2015). Developing pre-service teachers' noticing of students' understanding of the derivative concept. International journal of science and mathematics education, 13(6), 1305-1329. https://doi.org/10.1007/ s10763-014-9544-y

Schorr, R., \&; Lesh, R. (2003). A modeling approach for providing teacher development. In R. A. Lesh \& H. M. Doerr (Eds.), Beyond constructivism: Models and modeling perspectives on mathematics problem solving; learning; and teaching (pp. 141-158). Lawrence Erlbaum.

Schwartz, C. (2015). Developing the practice of teacher questioning through a K-2 elementary mathematics field experience, Investigations in Mathematics Learning, 7(3), 30-50. https://doi.org/10.1080/24727466.2015.11790344

Shulman, L. S. (1986). Those who understand: Knowledge growth in teaching. Educational Researcher, 15(2), 4-14. https://doi.org/ 10.3102/0013189X015002004

Shulman, L. S. (1987). Knowledge and teaching: Foundations of the new reform. Harvard Educational Review, 57(1), 1-22. https://doi.org/10.17763/haer.57.1.j463w79r56455411

Star, J. R., \& Strickland, S. K. (2008). Learning to observe: Using video to improve preservice mathematics teachers' ability to notice. Journal of Mathematics Teacher Education, 11, 107-125. https://doi.org/10.1007/s10857-007-9063-7

Steffe, L. P. (1991). The constructivist teaching experiment: Illustrations and implications. In E. von Glasersfeld (Ed.), Radical constructivism in mathematics education (pp. 177-194). Kluwer. https://doi.org/10.1007/0-306-47201-5_9

Steffe, L. P., \& Cobb, P. (1983). Cognitive development and children's solutions to verbal arithmetic problems: A critique. Journal for Research in Mathematics Education, 14, 74-76. https://doi.org/10.2307/748799

Steffe, L. P., \& Thompson, P. W. (2000). Teaching experiment methodology: Underlying principles and essential elements. In R. Lesh \& A. E. Kelly (Eds.), Research design in mathematics and science education (pp. 267-307). Erlbaum.

Stockero, S., Rupnow, R. L., \& Pascoe, A. E. (2017). Learning to notice important student mathematical thinking in complex classroom interactions. Teaching and Teacher Education, 63, 384-395. https://doi.org/10.1016/j.tate.2017.01.006

Tang, S. Y. F., \& Chow, A. W. K. (2007). Communicating feedback in teaching practice supervision in a learning-oriented field experience assessment framework. Teaching and Teacher Education, 23, 1066-1085. https://doi.org/10.1016/j.tate.2006.07.013

van Es, E. A., \& Sherin, M. G. (2002). Learning to notice: Scaffolding new teachers' interpretations of classroom interactions. Journal of Technology and Teacher Education, 10, 571-596.

van Es, E. A., \& Sherin, M. G. (2008). Mathematics teachers" "learning to notice" in the context of a video club. Teaching and Teacher Education, 24, 244-276. https://doi.org/10.1016/j.tate.2006.11.005

Weiland, I., Hudson, R., \& Amador, J. (2014). Preservice formative assessment interviews: The development of competent questioning. International Journal of Science and Mathematics Education, 12, 329-352. https://doi.org/10.1007/s10763-013-9402- 
APPENDIX: Codes, Categories, and Themes Emerged in This Study

\begin{tabular}{|c|c|c|}
\hline Themes & Categories & Description of the categories and codes \\
\hline \multirow[t]{6}{*}{$\begin{array}{l}\text { Field } \\
\text { experience } \\
\text { as a course } \\
\text { to prepare } \\
\text { teachers }\end{array}$} & Practice & $\begin{array}{l}\text { Field experience gave the opportunity of practice for: } \\
\text { - communicating with students, } \\
\text { - identifying students' thinking, } \\
\text { - using students' thinking in lesson planning, } \\
\text { - teaching, and } \\
\text { using feedbacks of colleagues to revise lesson }\end{array}$ \\
\hline & Disadvantages & $\begin{array}{l}\text { - Completing reflection forms for FAIs, lesson plans, teaching, and MB presentation handout is } \\
\text { - Teaching as a pair of pre-service teachers } \\
\text { - Not having experience in teaching in small group settings } \\
\text { - Not easy to take observation notes }\end{array}$ \\
\hline & $\begin{array}{l}\text { Course } \\
\text { relations }\end{array}$ & $\begin{array}{l}\text { Field experience is related to other classes, especially science and mathematics methods course } \\
\text { - Teacher education courses are not isolated from each other, rather complementing each other }\end{array}$ \\
\hline & $\begin{array}{l}\text { Self- } \\
\text { improvement }\end{array}$ & $\begin{array}{l}\text { FE helped the pre-service teacher to improve and identify students' thinking } \\
\text { - Helped development of teacher identity } \\
\text { - Realized the need of knowing more than just knowing how math ideas were taught to the pre- } \\
\text { - Rervice teacher and how she learned them } \\
\text { - More confident in teaching math and science }\end{array}$ \\
\hline & $\begin{array}{l}\text { Concerns } \\
\text { about reality }\end{array}$ & $\begin{array}{l}\text { Have concerns about whether it can be done in real teaching } \\
\text { - In spite of believing the value of FAI and MB, having concerns about their applicability in a } \\
\text { classroom setting } \\
\text { - Lesson study is more applicable as a teacher }\end{array}$ \\
\hline & Lesson study & $\begin{array}{l}\text { Lesson Study } \\
\text { - Easy to have teachers in the school to collaborate with } \\
\text { - Important to get feedback from other teachers to improve lesson }\end{array}$ \\
\hline \multirow[t]{3}{*}{$\begin{array}{l}\text { Formative } \\
\text { assessment } \\
\text { of student } \\
\text { thinking }\end{array}$} & Disadvantages & $\begin{array}{l}\text { Disadvantages of FAI } \\
\text { - Difficult to do when the other group of pre-service teachers prepared FAI questions, but when } \\
\text { she did the FAI } \\
\text { - Difficult to do FAI when one kid needs more wait time than the other one } \\
\text { - Difficult to do FAI when one kid is talkative while the other one was quiet. } \\
\text { - Difficult to probe when interviewing about the content which she was not confident enough }\end{array}$ \\
\hline & $\begin{array}{l}\text { Improvement } \\
\text { and confidence }\end{array}$ & $\begin{array}{l}\text { Improvements and confidence } \\
\text { - Increased confidence in interviewing over time } \\
\text { - Improved questioning skills over time }\end{array}$ \\
\hline & $\begin{array}{l}\text { Concerns and } \\
\text { suggestions }\end{array}$ & $\begin{array}{l}\text { Uses, concerns, and suggestions about making FAIs better } \\
\text { - Questioning in a non-threatening way } \\
\text { - } \text { Being encouraging rather than being evaluative } \\
\text { - Probing to understand the sources of students' errors and misconceptions }\end{array}$ \\
\hline \multirow{6}{*}{$\begin{array}{l}\text { Building } \\
\text { models } \\
\text { of student } \\
\text { thinking }\end{array}$} & Model building & $\begin{array}{l}\text { Description of the } \mathrm{MB} \\
\quad \text { Steps taken to do } \mathrm{MB}\end{array}$ \\
\hline & Model & $\begin{array}{l}\text { Description of model } \\
\text { - What the student knows and does not know } \\
\text { - Possible to have a generalizable model to other students }\end{array}$ \\
\hline & $\begin{array}{l}\text { Use of } \\
\text { transcription }\end{array}$ & $\begin{array}{l}\text { The use of transcription } \\
\qquad \quad \text { Transcription process, itself, informing about students' thinking }\end{array}$ \\
\hline & $\begin{array}{l}\text { Use of group } \\
\text { work }\end{array}$ & $\begin{array}{l}\text { Importance of group interaction and group discussion in } \mathrm{MB} \\
\text { - } \quad \text { MB with peers is deeper than individual MB } \\
\text { - Other teachers notice different things } \\
\text { - Possible for teachers to compare models of their own students' thinking with models of others }\end{array}$ \\
\hline & Disadvantages & $\begin{array}{l}\text { Disadvantages of MB } \\
\text { - } \quad \text { Repetitive discussion in MB with peers } \\
\text { - } \quad \text { Main work is done by the model builder } \\
\text { Mork is done individually }\end{array}$ \\
\hline & Suggestions & $\begin{array}{l}\text { Suggestions about MB } \\
\qquad \quad \text { Building the model collaboratively }\end{array}$ \\
\hline $\begin{array}{l}\text { Relationship } \\
\text { between FAI } \\
\text { and MB }\end{array}$ & $\begin{array}{l}\text { Positive } \\
\text { connections }\end{array}$ & $\begin{array}{l}\text { FAI and MB's complementing and feeding each other } \\
\text { - FAIs and MBs are connected } \\
\text { - MB is an evidence-based interpretation of students' thinking while FAI is more superficial }\end{array}$ \\
\hline
\end{tabular}

